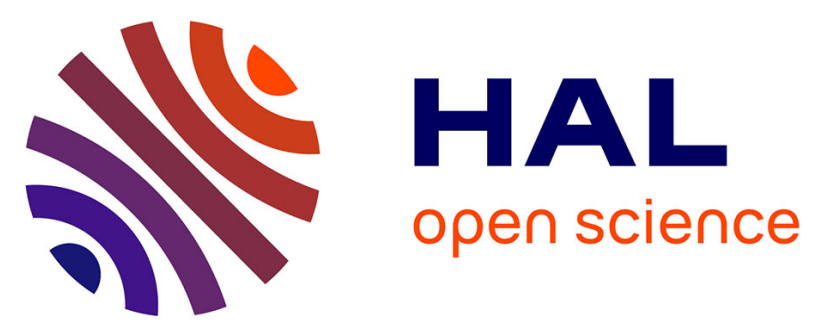

\title{
Presentation of the french national project DRIVE: experimental data for the evaluation of hydrogen risks onboard vehicles, the validation of numerical tools and the edition of guidelines
}

Lionel Perrette, Henri Paillere, Guillaume Joncquet

\section{To cite this version:}

Lionel Perrette, Henri Paillere, Guillaume Joncquet. Presentation of the french national project DRIVE: experimental data for the evaluation of hydrogen risks onboard vehicles, the validation of numerical tools and the edition of guidelines. Society of automative engineer world Congress 2007, Apr 2007, Detroit, United States. pp.NC. ineris-00976178

\section{HAL Id: ineris-00976178}

https://hal-ineris.archives-ouvertes.fr/ineris-00976178

Submitted on 9 Apr 2014

HAL is a multi-disciplinary open access archive for the deposit and dissemination of scientific research documents, whether they are published or not. The documents may come from teaching and research institutions in France or abroad, or from public or private research centers.
L'archive ouverte pluridisciplinaire HAL, est destinée au dépôt et à la diffusion de documents scientifiques de niveau recherche, publiés ou non, émanant des établissements d'enseignement et de recherche français ou étrangers, des laboratoires publics ou privés. 


\title{
Presentation of the French national project DRIVE: Experimental Data for the Evaluation of hydrogen Risks onboard vehicles, the Validation of numerical tools and the Edition of guidelines
}

\author{
Lionel PERRETTE \\ INERIS / France \\ Henri PAILLERE \\ CEA (LTMF) / France
}

Guillaume JONCQUET

PSA, Centre Technique de Carrières-sous-Poissy / France

\begin{abstract}
The everyday use of hydrogen in the transport sector requires high safety standards. Safety requirements must be addressed as a key issue for fuel cell car development. Therefore, it becomes crucial to have experimental data on hand in order to provide realistic and reliable risk assessment and to be able to really know the extent of safety margins taken. In such a context, the National Institute of Industrial Environment and Risks (INERIS) along with the French Atomic Energy Commission (CEA), the French automotive manufacturer PSA PEUGEOT CITROËN and the research Institute on unstable phenomena (IRPHE) recently started a research programme entitled DRIVE. This programme aims at providing experimental and numerical results for the safe design of hydrogen vehicles. Fields of investigation cover the whole range of phenomena that can be encountered in hydrogen accidents, from leakage to dispersion, ignition and finally combustion. The work programme and early results are presented in this article.
\end{abstract}

\section{INTRODUCTION}

The everyday use of hydrogen in the transport sector requires high safety standards. Safety requirements must be addressed as a key issue for fuel cell car development. It is therefore a necessity to fully understand and investigate explosion and fire hazards associated with the use of hydrogen and to come up with practical and realistic means to control these hazards. Although the experience and safety record of hydrogen as an industrial gas is significant, it turns out not to be applicable to the future decentralised use of moderate quantities of hydrogen. Data specific to that use are becoming crucial in order to provide realistic risk assessment and to be able to specify expected safety performances.

\section{PROGRAMME OBJECTIVES}

This project which gathers together industrial expertise of the car manufacturer PSA PEUGEOT CITROËN as well as technical and scientific skills of CEA, IRPHE and the co-ordinator INERIS aims at providing experimental and numerical results to better assess hazards when handling hydrogen onboard vehicles. Results will contribute to strengthen risk assessment studies in terms of hazard quantification as well as to propose innovative solutions for the handling of hydrogen in cars compatible with public use.

The work programme is split into 4 items: the automotive system, hydrogen dispersion, hydrogen ignition and combustion and finally results dissemination. The second and the third items focus on the hazardous phenomena one would consecutively encounter when dealing with hydrogen accidents. The accidental chain is illustrated by the figure below.

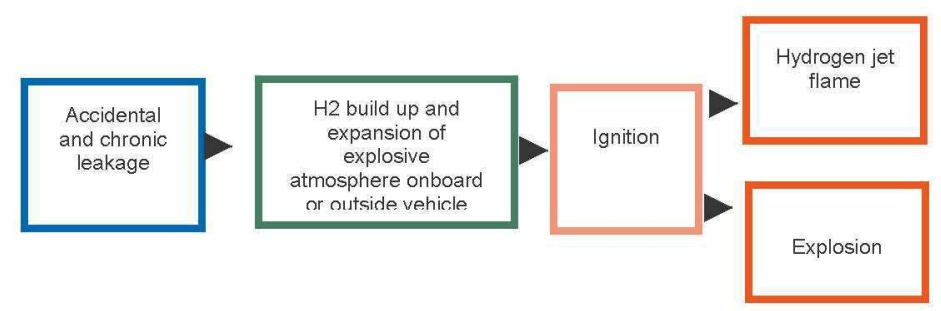


The list below indicates some of the safety challenges that face car manufacturers:

- Safe pressurised storage design (thermal insulation, use and location of pressure relief devices (PRD), enclosed or open compartment for storage...) and location of the pressurised storage in order to prevent burst due to thermal and mechanical aggressions as well as to control consequences of accidental leakage or PRD releases.

- Adequate control of standing flames fed by minor undetected leaks,

- Appropriate equipment design (choice of material and technology) and location (segregation,, enclosure,...) in order to control ignition sources whether mechanical, electrical or electrostatic in normal operations,

- Safe handling of hydrogen purged outside vehicle,

- Effective control of explosive atmospheres in confined or semi-confined spaces on-board vehicles (engine compartment) or outside the vehicle (underbody, garages...). That also includes ensuring that hydrogen will never penetrates into the passenger compartment.

Aside from the items above, one of the great challenges consists in setting an appropriate limit to segregate tolerable accidental releases versus unacceptable ones. Such a limit would contribute to set the expected performance of the leak detection and leak interruption systems whether based on atmospheric detection or on direct measurement such as flow or pressure drop. Ideally, a vehicle should be able to run without leak detection systems having in mind that reliability of such detection system is so far moderate and that maintenance is rather constraining. Chronic leakage is also an issue since the no-leak objective does not seem to be realistic. Therefore, upper tolerable limit should also be specified for chronic leakage along with design measures to ensure that hydrogen can never accumulate to form an explosive mixture.

Finally, CFD tools currently and intensively used by car manufacturers to design vehicles (aerodynamic studies for instance) should also be able to provide reliable results when computing normal or accidental release scenarios for hydrogen vehicles.

Safe design practices should finally be shared among manufacturers to promote the high safety standard expected for the public use of hydrogen.

\section{DETAILED PRESENTATION OF THE WORK PROGRAMME AND EARLY RESULTS}

\section{WORK PROGRAMME}

This project started early 2006 in the framework of the first call for proposals of the National Research Agency (ANR). It will last for three years. Its work programme is made of 4 main modules:
- vehicle safety,

- hydrogen release and dispersion,

- hydrogen ignition and combustion (explosion or jet flame),

- and finally results compilation and dissemination.

The vehicle safety module includes a thorough risk assessment in order to identify hazardous situations (causes, consequences). Outputs from this module will shape the content of the experimental and modelling work in terms of hazardous situations to investigate with the objective of obtaining better quantification and therefore better risk assessment and risk control. The vehicle safety module that concentrates on hydrogen equipment and potential ignition sources onboard vehicles goes down to component level.

Within the hydrogen release and dispersion module, we will then experimentally look at hydrogen component leakage in order to quantify them. Both chronic and accidental hydrogen leakage, as well as hydrogen emissions (purges, pressure relief systems) will be considered. These values will then serve as references to build the test matrix for hydrogen releases (free and impinged) on board the vehicle as well as in confined spaces.

These release experiments will be carried out with helium as well as with hydrogen. The size and location of explosive atmospheres will be monitored for various leaking rate and location.

Within the third module, we will concentrate on hydrogen ignition with vehicle components as well on hydrogen combustion (flame or explosion). Ignition potentiality of car components (fans, electronic cards, electric engines, braking systems...) will be investigated through practical testing. In parallel, explosion experiments will be undertaken in order to assess the destructive potential of explosive atmospheres (in accordance with hydrogen dispersion findings) in more or less obstructed environments. In a later stage, combustion tests will take place on board vehicles. Hydrogen flames will also be considered at two different scales; on one hand, effect of large hydrogen flame resulting for instance from a PRD release and on the other hand, standing flames fed by minor leaks. For the latter point we will look at the ease with which ignition can occur as well as flame sustainability depending on upstream pressure and leaking orifice size. Excessive fire hazards due to the use of hydrogen can possibly be more critical than explosive atmospheres themselves that concentrate most of today's concerns. In the frame of the last module, experimental learning will be turned into practical graphs to facilitate risk quantification. Recommendations on best practices for vehicle design will also be drafted. Topics such as maximum allowable explosive volume, control of ignition sources and location of hydrogen components... will be addressed in final public reports. Results will be discussed during dedicated seminars. 
This project will not investigate the safety of highpressure hydrogen storage in terms of potentiality for catastrophic failure when exposed to mechanical aggression or external fire. Issues such as fuse location on tanks or thermal insulation will not be looked at in the frame of this project. However, potential leaks as well as PRD releases consequences (explosive atmosphere under vehicle, jet fire) will be experimentally considered. Leakage during refuelling will not be considered either.

More detailed content and progress of some of the work themes is given below.

\section{WORK TOPICS}

Objectives, methodology, tools, basic background information and early results will be presented for each of the topics below:

1. vehicle risk assessment,

2. leak quantification,

3. hydrogen dispersion on board and outside the vehicle,

4. hydrogen ignition by vehicle components,

5. hydrogen explosion,

6. \& hydrogen flames.

\section{VEHICLE RISK ASSESSMENT}

\section{OBJECTIVE}

Risk assessment helps to evaluate and demonstrate through a systematic and consistent approach that a hydrogen vehicle whether of a prototypic or a series production type is as safe as a conventional one. Within this project this early work will help us to select hazardous situations to be studied and therefore to shape the experimental programme.

\section{STEPS}

Usual risk assessment steps are the following:

- identify unwanted events and associated causes and consequences,

- evaluate their criticity,

- and take appropriate actions to bring risk down to an acceptable level.

\section{TOOLS}

Four tools are mainly used to contribute to the risk assessment studies: functional analysis preliminary risk analysis, fault trees and then Failure Mode and Effect Analysis (FMEA).

First of all, a functional analysis was undertaken. It helps to identify system functions and associated internal and external constrains. Then a preliminary risk assessment was carried out. This simple methodology helps to highlight the most unwanted events and to initiate discussions on severity and severity levels. For each vehicle mode (running, stand by, maintenance...) the following unwanted events are investigated:

- shift in internal system functions and system constrains,

- impact from the system on its environment,

- and finally, impact from the environment on the studied system.

All identified unwanted events were then ranked according to severity criteria. The severity scale consists of four levels. The highest ones 4 and 3 are those further considered in the study. Level 4 is associated with death or injury on people and level 3 means that the vehicle can no longer be used because of a break down. Level 3 and 4 unwanted events were then further investigated using the fault tree methodology. This graphical methodology helps to visualise steps and failure combinations that lead to the top unwanted event.

Finally, a failure mode and effect analysis (FMEA) was carried out. This systematic and inductive methodology helps:

- to assess consequences of component failures (loss or alteration of associated function) on the vehicle and its user,

- to identify component failure modes that can impact safety,

- and finally to propose corrective safety actions in the course of the design process.

A typical FMEA table similar to the one used in the project is pictured below:

\begin{tabular}{|c|c|c|c|c|c|c|c|}
\hline 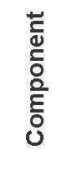 & 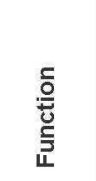 & 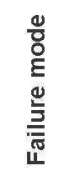 & 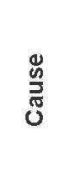 & 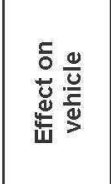 & 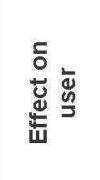 & 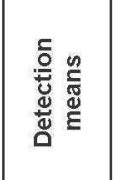 & 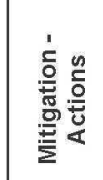 \\
\hline 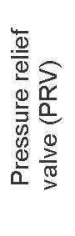 & 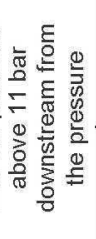 & 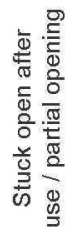 & 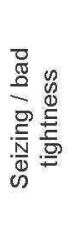 & 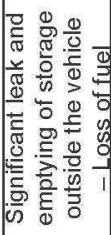 & 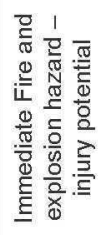 & 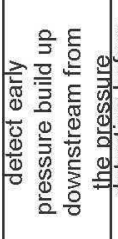 & 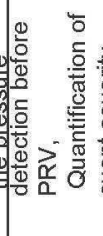 \\
\hline$\vdots$ & & & & & & & \\
\hline
\end{tabular}

Table 1: FMEA table used in the risk assessment process

\section{EARLY RESULTS}

Identified unwanted events when using hydrogen onboard vehicle include:

- fire onboard vehicles, 
- explosive atmospheres and ignition wherever onboard or outside the vehicle,

- the burst of the pressurised tank,

- high pressure jets.

All the selected unwanted events are linked either with the use of hydrogen or with the handling of pressurised gas. Unwanted events associated with high voltage or other non specific hazards are not considered in this programme.

\section{LEAK QUANTIFICATION}

\section{OBJECTIVE}

The objective of this task consists in experimentally measuring chronic and accidental leak rates (external aggression, human error...) associated with key components of the hydrogen feed line and the hydrogen conversion system. Accidental leaking rates to be evaluated include likely situation such as bad fitting (insufficient clamping), erroneous fitting, missing or damaged sealant. Ageing will be looked at through repeated dismantling of hydrogen connections. Leak caused by organic failures of components (quality issues, internal ageing) quantification will be forwarded to component manufacturers. Design related hydrogen emissions (PEMFC purge, PRV...) will also be taken into consideration. Investigated pressures will cover the full range from the 700 bar working pressure for the highpressure line down to few bars for the hydrogen conversion system. Both hydrogen and helium gas will be used in order to assess the appropriateness to use helium for leak quantification.

These realistic and practical figures gained from these tests will serve as input parameters for further hydrogen dispersion and combustion experiments. These values will also be of a great help for risk assessment studies.

\section{STEPS}

The study includes four main steps. The first one consists in extracting and referencing leak scenarios from the risk assessment study. The next one will consist in selecting components and test conditions (pressure, damage free / damaged equipment). Selection criteria include for instance likelihood and severity of leak, lack of data from manufacturers or gas component not initially designed for hydrogen use. Then, tests will be carried out with the experimental set up shown further down. Finally results will be recorded and analysed.

\section{BACKGROUND INFORMATION}

Literature shows that various vehicles related leak rates have been investigated in the frame of dispersion experiments. As shown in table 2, these investigated rates vary from $0.5 \mathrm{~g} / \mathrm{min}$ (BMW [1]) up to $100 \mathrm{~g} / \mathrm{min}$
$\left(\mathrm{Cfcp}^{1}\right.$ [2]) with an average value around $10-20 \mathrm{~g} / \mathrm{min}$. It is interesting to notice that these values vary in a large domain. Besides, except for the BMW tests, there is not any obvious link between investigated cases and specific component leakage.

Regarding component leakage the Cfcp document indicates that the fill up point and the pressure relief point are considered as the only way for the hydrogen tank to leak out. As far as other components are concerned, the pressure regulator, piping and fittings were considered as components able to leak out whatever the operating pressure (high-pressure and low-pressure). The value of $20 \mathrm{CFM}(12.77 \mathrm{~g} / \mathrm{min})$, referenced in this document, is based on the assumption that that the onboard computer is capable of shutting down hydrogen flow upon receiving a signal detecting a flow larger than 20 CFM when the engine is off. The Japanese regulation for hydrogen vehicle ${ }^{2}$ proposes a leak threshold of $11,8 \mathrm{~g} / \mathrm{min}$ (or $131 \mathrm{~L} / \mathrm{min}$ ) that should not be reached in case of leakage after vehicle collision. This leakage is assumed to have the same calorific value as today's admissible value for gasoline. However, associated explosive atmosphere and consequences have not been taken into consideration. The same document indicates that helium can be used instead of hydrogen for leak tests as long as a 1.33 multiplication factor of the leak volumetric flow is used.

Regarding purge management, the Japanese regulation indicates also that no purged gas in excess of $4 \%$ of hydrogen concentration shall be discharged or leaked to the atmosphere.

As far as the GRPE Informal Group on Hydrogen/Fuel Cell Vehicles work is concerned [3], no maximum allowable leakage value or leakage value to be detected is proposed.

The work carried out in the framework of the DRIVE project will propose some realistic data specific to hydrogen components and hydrogen fittings. These data will enrich somehow empirical data proposed so far.

\section{TOOLS}

Components will be connected to pressure sources according to the figure below. Components will be placed inside a closed $2 \mathrm{~m} 3$ insulated sphere inside where both pressure and temperature are monitored. Component leak rate measurement is directly linked to pressure variation inside the sphere.

\footnotetext{
${ }^{1}$ California Fuel Cell Partnership

${ }^{2}$ Attachment 100 - Technical standard for fuel systems of motor vehicles fueled by compressed hydrogen gas
} 

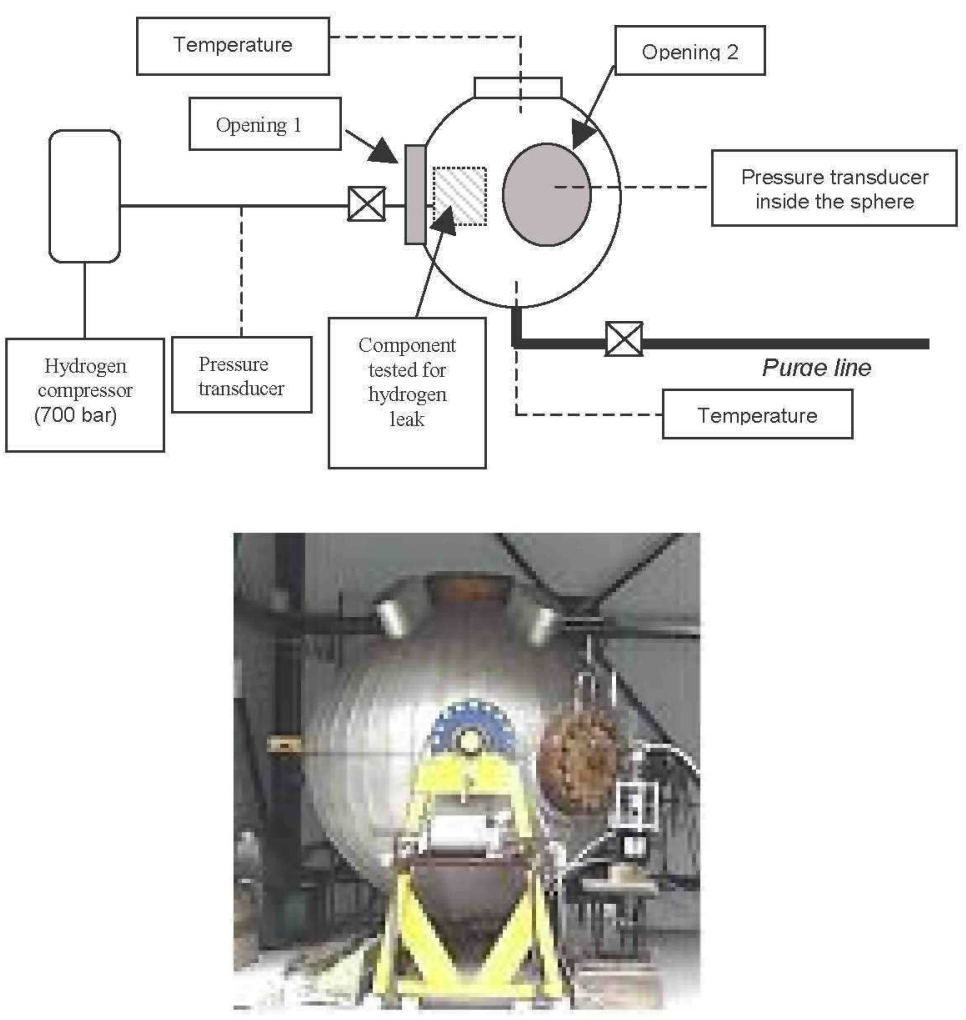

Figure 1: Experimental set up for leak quantification

\section{EARLY RESULTS}

At least, the following components will be tested: hydrogen connections, pressure regulator, phase separator, hydrogen pump, solenoid valve \& components made of polymeric or plastic type materials.

\section{HYDROGEN DISPERSION ON BOARD AND OUTSIDE VEHICLE (CONFINED SPACES)}

\section{OBJECTIVES}

The objectives of this study are to investigate, experimentally and numerically, different types of leaks and the dispersion of hydrogen either inside the vehicle or outside the vehicle in the most critical situation, that is when the vehicle is parked in an enclosed space such as a private garage. The mechanisms for the build-up of a potentially explosive mixture of hydrogen and air will be studied in detail, and effects of confinement and ventilation will be assessed.

\section{STEPS}

The experimental programme will consist of leak and dispersion tests in a full-scale garage as well as onboard a vehicle. Both helium and hydrogen will be used. The test matrix will be elaborated from the leak quantification tests, the preliminary risk assessment study, and some pretest calculations using CFD (Computational Fluid Dynamics) codes will be performed to optimise the instrumentation set-up (location, number of sensors). After the tests have been performed, the CFD tools will be validated on a series of experiments, including some involving passive or active ventilation. Finally, the CFD tools will be used to perform parametric studies and to identify worse case scenarios and how they can be mitigated (for example by design of passive or active ventilation).

\section{BACKGROUND INFORMATION}

The table below summarises past hydrogen leak hypotheses and dispersion experiments in confined spaces.

\begin{tabular}{|c|c|c|c|}
\hline $\begin{array}{l}\text { Data } \\
\text { source }\end{array}$ & $\begin{array}{c}\text { Experimental } \\
\text { configuration and } \\
\text { objectives }\end{array}$ & $\begin{array}{l}\text { Leak rate } \\
\text { proposed or } \\
\text { investigated in } \\
\mathrm{g} / \mathrm{min}\end{array}$ & Remarks \\
\hline $\begin{array}{c}\text { Swain } \\
\text { garage - } \\
1998[4] \& \\
\text { [5] }\end{array}$ & $\begin{array}{l}\text { Assess how should } \\
\text { existing garages be } \\
\text { modified to make } \\
\text { them suitable for } \mathrm{H} 2 \\
\text { vehicles }\end{array}$ & $10.2 \mathrm{~g} / \mathrm{min}$ & Low exit velocity $(0.1 \mathrm{~m} / \mathrm{s})$ \\
\hline $\begin{array}{c}\text { Swain } \\
\text { hallway - } \\
1999[6\}\end{array}$ & CFD validation & $4.8 \mathrm{~g} / \mathrm{min}$ & Low exit velocity $(0.1 \mathrm{~m} / \mathrm{s})$ \\
\hline $\begin{array}{l}\text { California } \\
\text { fuel cell } \\
\text { Partnershi } \\
\text { p - July } \\
2004[2]\end{array}$ & $\begin{array}{c}\text { The objective was to } \\
\text { numerically } \\
\text { evaluate } \\
\text { consequences } \\
\text { (explosive } \\
\text { atmosphere volume) } \\
\text { of hydrogen leakage } \\
\text { in confined } \\
\text { environment such as } \\
\text { garages. } \\
\text { Two undercarriage } \\
\text { configurations } \\
\text { considered } \\
\end{array}$ & 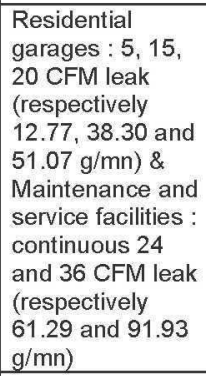 & $\begin{array}{l}\text { The assumption is that the } \\
\text { on-board computer is } \\
\text { capable of shutting down } \\
\text { hydrogen flow upon } \\
\text { receiving a signal detecting } \\
\text { a flow larger than } 20 \text { cubic } \\
\text { feet per minute (CFM) flow, } \\
\text { 'leak', when the vehicle is } \\
\text { dormant. This leak rate } \\
\text { corresponds to a fuel cell } \\
\text { power output of about } 50 \\
\text { kW }\end{array}$ \\
\hline JARI [7] & $\begin{array}{l}\text { Examine the } \\
\text { diffusion behaviour } \\
\text { of hydrogen in an } \\
\text { enclosed space with } \\
\text { various release } \\
\text { speed Hydrogen } \\
\text { was released } \\
\text { continuously from } \\
\text { the center of the box } \\
\text { bottom surface }\end{array}$ & $0,84 \mathrm{~g} / \mathrm{min}$ or 10 & $\begin{array}{l}\text { It was found that with } \\
\text { change in release speed } \\
(0.1,0.2 \text { and } 3.4 \mathrm{~m} / \mathrm{s} \\
\text { (corresponding exit } \\
\text { diameters are } 46,33 \text { and } 8 \\
\mathrm{~mm} \text { respectively) there } \\
\text { was a moderate variation } \\
\text { in the horizontal hydrogen } \\
\text { diffusion along the bottom } \\
\text { surface and in the lift of the } \\
4 \%+\text { combustible mixture }\end{array}$ \\
\hline $\begin{array}{l}\text { BMW } \\
\text { tests [1] }\end{array}$ & $\begin{array}{c}\text { BMW wanted to } \\
\text { experimentally } \\
\text { demonstrate that } \\
\text { maximum leakage in } \\
\text { a confined room } \\
\text { (garage) would not } \\
\text { induce hazardous } \\
\text { explosive } \\
\text { atmosphere with } \\
\text { minimum natural } \\
\text { ventilation. }\end{array}$ & $\begin{array}{c}1 \mathrm{~g} / \mathrm{min} \\
0.5 \mathrm{~g} / \mathrm{min}\end{array}$ & $\begin{array}{c}1 \mathrm{~g} / \mathrm{min} \text { is considered to be } \\
\text { the maximum escape } \\
\text { volume of hydrogen in the } \\
\text { event of a fault. } \\
0,5 \mathrm{~g} / \mathrm{s} \text { concerns less } \\
\text { severe cases. Hydrogen is } \\
\text { stored under cryogenic } \\
\text { form. These values are } \\
\text { based on hydrogen boil off. }\end{array}$ \\
\hline $\begin{array}{l}\text { Motor } \\
\text { Vehicle } \\
\text { Fire } \\
\text { Research } \\
\text { Institute } \\
\text { USA [8] }\end{array}$ & $\begin{array}{c}\text { Assess } \\
\text { consequences of } \\
\text { hydrogen released if } \\
\text { ignited in the vehicle } \\
\text { underbody as well } \\
\text { as in the engine } \\
\text { compartment }\end{array}$ & $\begin{array}{c}48 \mathrm{~g} / \mathrm{min} \& 24 \\
\mathrm{~g} / \mathrm{min} \text { through a } \\
1.6 \mathrm{~mm} \text { orifice } \\
\text { nozzle }\end{array}$ & $\begin{array}{c}\text { No indication given on why } \\
\text { these data have been } \\
\text { chosen. }\end{array}$ \\
\hline
\end{tabular}

Table 2: Hydrogen leak cases in confined spaces extracted from the literature

Compared with existing experiments and data, DRIVE will investigate wider leak rates and release conditions spectrum with more elaborate measurement techniques, in terms of gas concentration and velocity and turbulence measurements. The new tests will be the 
most detailed and finely instrumented tests for the study of hydrogen leaks. The objective is clearly to produce data both for risk assessment purpose, and to validate CFD tools, which are now well recognised to be potentially the most accurate and reliable computational tool for assessing consequences of accident scenarios.

\section{TOOLS}

The development of a full-scale garage and a quasi nonintrusive (due to their small size) sensor network (catharometric measurement type) is currently in progress. Mass flow controller of various ranges will be used in order to control leak flow. Hydrogen or helium concentration will be measured with the help of the catharometric sensors grid. Non intrusive velocimetry measurements will be undertaken through particle image velocimetry (PIV) and Laser Doppler Velocimetry (LDV). Transparent walls will be mounted on the garage to allow measurements. Ventilation will be managed with the help of either an extractor or a fan. The dimensions of the garage are those of a typical European garage for a single vehicle, and it is fitted with an overhead pivoting door. The garage will be fitted with vents which can provide either passive or active ventilation or extraction.

Computational Fluid Dynamics tools will be used for pretest calculations, as well as to analyse the tests once the CFD codes have been completely validated. One of the CFD outputs that will be of most use for safety assessment is the time-evolution of the volume of explosive atmosphere (for example the volume of gas mixtures above $4 \%$ of $\mathrm{H} 2$ ). The effect of leak location, direction, impingement on nearby obstacles as well as presence or absence of ventilation on the evolution of this cloud will be investigated in detail.

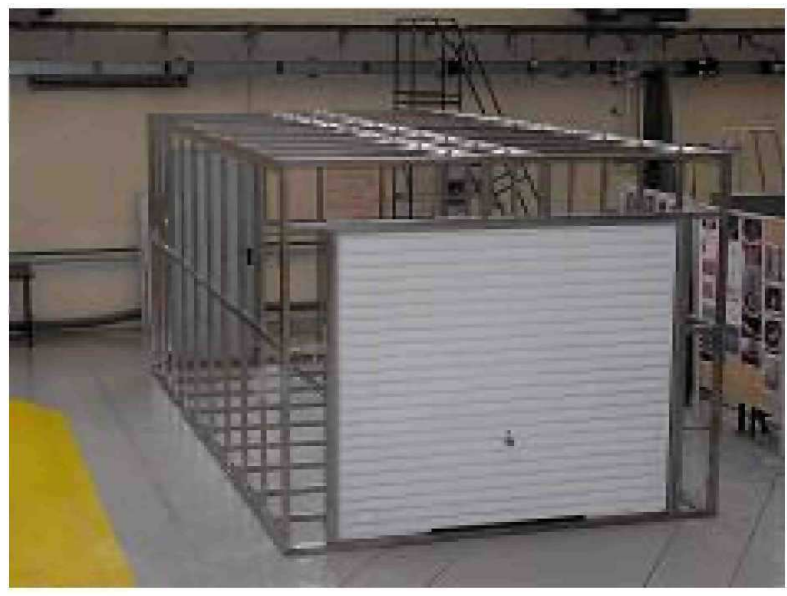

\begin{tabular}{|c|c|c|}
\cline { 2 - 3 } \multicolumn{1}{c|}{} & $\begin{array}{c}\text { External } \\
\text { dimensions }\end{array}$ & $\begin{array}{c}\text { Internal } \\
\text { dimensions }\end{array}$ \\
\hline Length $(\mathrm{m})$ & 5.84 & 5.76 \\
\hline Width $(\mathrm{m})$ & 3.04 & 2.69 \\
\hline High $(\mathrm{m})$ & 2.5 & 2.42 \\
\hline Volume $\left(\mathrm{m}^{3}\right)$ & 44.88 & 41.26 \\
\hline
\end{tabular}

Figure 2: Garage skeleton (top) and garage dimensions (bottom)

\section{EARLY RESULTS}

The first tests are scheduled in the second semester of 2006, and will first address simple release scenarios with no obstacles and then release scenarios with a vehicle mock-up. Extensive work is under way to build and test the experimental set up, as well as to test and calibrate the sensors, both under air/helium and air/hydrogen flows.

\section{HYDROGEN IGNITION BY VEHICLE COMPONENTS}

\section{OBJECTIVE}

The objective of this work is to assess the ignition potential of some of the electrical and mechanical components and to identify best practices for the design and the positioning of vehicle components.

\section{STEPS}

Though not applicable to vehicles, the same strategy as the one of the ATEX 94/9CE [9] \& ATEX 99/92CE [10] is followed. Basically, it consists in demonstrating that components have no ignition potential under normal circumstances whenever an explosive atmosphere can form accidentally.

The first step therefore consists in listing mechanical and electrical components in the vicinity of hydrogen systems. Then, some of them will be selected to undertake ignition tests in dedicated chambers. Based on results, recommendations will be made regarding the design and the location of the components.

\section{BACKGROUND INFORMATION}

In the course of this project, we have been looking at cross-experiences from natural gas vehicles (NGV) as well as from industrial vehicles that could accidentally drive into an explosive atmosphere (fork lift trucks). Regarding NGV vehicles, no recommendation at all is found regarding protection or segregation of electrical equipment [11]. As far as forklift trucks are concerned (category 3 vehicle for type 2 zone), the EN 1755 [12] standard gives a few hints which include: 
- minimum distance to prevent mechanical frictions or limit speed at which friction can occur (brakes, clutch,...),

- bounding of all mechanical parts to ensure same electric potential,

- enclosing of electrical equipment to limit combustible gas ingress whenever the forklift drives through an explosive cloud,

- installing gas detection onboard forklift truck. A $10 \%$ LFL concentration triggers an alarm. A $25 \%$ LFL concentration stops the forklift,

- and also, limiting maximum surface temperatures when in use.

Now, looking at GRPE [3] latest draft provisions, one could notice quite a few recommendations on electrical equipment. That includes:

- preventing hydrogen ingress into power supply connections where hydrogen leaks are possible (paragraph 14.11.4.),

- providing sufficient insulation of electrical components to ensure that no current passes through hydrogen containing parts (paragraph 6.5.1)

- \& ensuring that electrical connections and components in the gas tight housing are constructed such that no sparks are generated (paragraph 14.10.3.)

\section{TOOLS}

Tests will be carried out inside an explosion chamber dedicated to test electrical or mechanical equipment. The picture below features a typical test chamber.

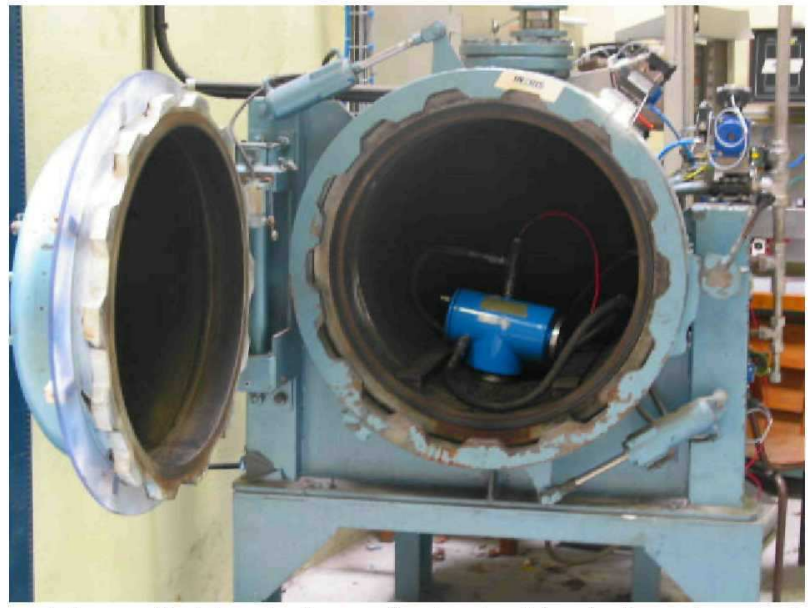

Figure 3: Front view of a typical test chamber to test ignition potential of equipment

\section{EARLY RESULTS}

So far, the following components have been selected for practical testing:

- the hydrogen compartment fan,

- the electric motor that drives the vehicle,

- the electrical converter,

- and the braking system
Moreover, some non-conductive material components have been selected in order to check whether or not they can lead to an electrostatic ignition hazard

Regarding early recommendations for the design of vehicle components in order to control ignition sources in normal use, the following can be proposed so far:

\begin{tabular}{|c|c|c|}
\hline $\begin{array}{c}\text { Compon } \\
\text { ent }\end{array}$ & $\begin{array}{c}\text { Referen } \\
\text { ces }\end{array}$ & State of the art design to control of ignition sources \\
\hline $\begin{array}{l}\text { Braking } \\
\text { system }\end{array}$ & $\begin{array}{l}\text { EN } \\
1755 \\
{[12]}\end{array}$ & 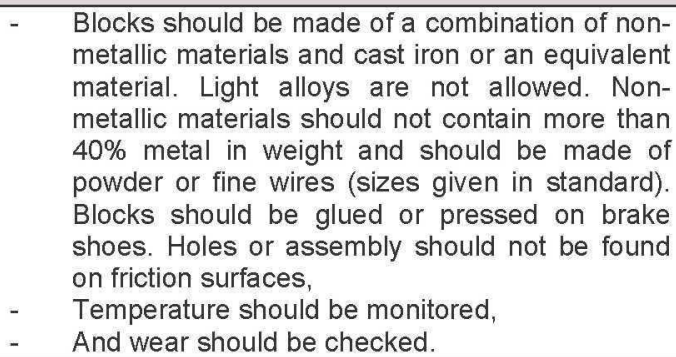 \\
\hline Fans & $\begin{array}{c}\text { EN } \\
50021 \\
{[13]}\end{array}$ & $\begin{array}{l}\text { - IP10 rating (IP:Protection Index for water and } \\
\text { dust penetration), on the output side and IP } 20 \\
\text { rating on the input side, } \\
\text { - } \\
\text { gistances between moving and fixed parts } \\
\text { between } 1 \text { and } 5 \mathrm{~mm} \text { ), } \\
3,5 \mathrm{~J} \text { shock test without hazardous deformation } \\
\text { (or } 2 \mathrm{~J} \text { if fans are physically protected against } \\
\text { shocks). }\end{array}$ \\
\hline $\begin{array}{c}\text { Sparkles } \\
\text { s drive } \\
\text { motors }\end{array}$ & $\begin{array}{c}\text { EN } \\
50021 \\
{[13]}\end{array}$ & $\begin{array}{l}\text { - IP } 54 \text { rating, } \\
\text { - Dielectric strength test to ensure sufficient } \\
\text { electric isolation, } \\
\text { - } \quad \text { Expectations on electrical couplings, } \\
\text { - Minimum distance between rotor and stator to } \\
\text { be implemented. }\end{array}$ \\
\hline
\end{tabular}

Table 3: State of the art design to control ignition sources for some key components

\section{HYDROGEN COMBUSTION}

\section{OBJECTIVE}

This work aims at defining maximum tolerable explosive volumes for various leakage environments and providing straightforward pressure/effect prediction rules for risk assessment. Test results will also be useful to evaluate the prediction potential of CFD tools.

\section{STEPS}

This experimental programme will first investigate pressure effects caused by the ignition of moderate and calibrated explosive volumes for various levels of confinement from free environment up to congested environment similar to those we can find onboard vehicles. Pressure prediction rules will be derived from these early tests. Then explosions will be carried out onboard vehicle following leakage flows and locations consistent with those found in the earlier work programme. These tests will also help us to evaluate the destructive potential of onboard vehicle explosions. 


\section{BACKGROUND INFORMATION}

Although not wanted, leaks will inevitably occur onboard vehicles. It is therefore a necessity to work on a maximum allowable explosive volume with tolerable associated effects. Once this limit is set, it will be a significant input to size safety barriers for leak detection and interruption. So far, the only "tolerable explosive volume" we found come from the industry. The European guide document for the implementation of ATEX 99/92CE directive [10] indicates, independently of the combustible gas considered that:

- an unconfined explosive atmosphere should always be considered hazardous when its volume is above 10 litres,

- and an explosive atmosphere in a closed room should always be considered hazardous when its volume is greater than $1 / 10000$ of the room volume.

Other work [15] investigated the limit of acceptable explosive volumes in natural gas turbine casings. The recommended safety criterion is that the natural gas flammable cloud volume should be less than $0.1 \%$ of the net enclosure volume. In addition to the above condition on the allowable size of a flammable gas cloud relative to the net enclosure volume, the flammable gas cloud volume should also be less than $1 \mathrm{~m}^{3}$ in all cases, irrespective of the enclosure volume. Safety systems have to be designed (detection, ventilation) in order to insure that these limits are never exceeded. One should mention that people would not be present inside the enclosure volume but are expected to stand nearby. Proposed acceptable explosive volumes are not susceptible to cause casing rupture and blast injuries.

Examples above illustrated confined and unconfined explosions as well as explosion with and without direct exposure of people. These various cases will be taken into consideration.

Regarding existing data on explosion experiments for moderate and calibrated explosion volumes in more or less confined environment, the review has not yet started. However, similar experiments will be carried out by $F Z K^{3}$ in the framework of the HySafe network.

For explosion onboard vehicles, we can mention experiments carried out by the Motor Vehicle Fire Research Institute USA [8] where they investigated hydrogen leakage in the engine compartment. They investigated various release rate and ignition delay. Test showed that the maximum engine compartment overpressure was 220 mbar. This maximum overpressure that caused the hood to bend was obtained for a $64 \mathrm{sec}$ release of $51 \mathrm{~g}$ of hydrogen. Shorter released produced overpressure of 10 mbar to 152 mbar.

\section{TOOLS}

\footnotetext{
${ }^{3}$ Forschungszentrum Karlsruhe
}

These tests are planed for 2007. The experimental set up has not been designed yet. Tests will most probably be combined with those undertaken by FZK in the framework of the HySafe network.

\section{HYDROGEN FLAME}

\section{OBJECTIVE}

This work aims on one hand at providing data on hydrogen flame length and on hydrogen flame radiation for some severe scenarios (significant leak under the hood, hydrogen escaping through the thermal fuse). Besides these tests, less severe cases will be investigated in order to study conditions under which a hydrogen flame cannot be sustained. Ease of ignition shall also be investigated for high and moderate pressures with various leak orifices. These latter cases address minor / non detectable leakage that do not cause any explosion hazard but could however cause a significant fire hazard whenever the vehicle is parked or driven.

\section{STEPS}

The work programme includes both an experimental and a numerical part. The first step will consist in selecting a set of realistic scenarios/situations to be investigated. The experimental set up for flame length and flame radiation has not yet been designed. Regarding flame length, both free and impinged jets will be looked at. Seeding will probably be used to visualise flames. As far as micro leaks are concerned, we will look at leak orifices most probably below $1 \mathrm{~mm}$ for various values of pressure.

\section{BACKGROUND INFORMATION}

It has been established experimentally that hydrogen discharges through circular orifices larger than a critical diameter sustains stable lifted flames irrespective of the reservoir pressure driving the release. At smaller diameter however, stable burning will only be achieved at operating pressures higher than a particular, diameter-dependant threshold [16].

Regarding vehicle related literature contributions, we can mention two practical contributions to the topic. First of all, we can mention the experimental work from the Motor Vehicle Fire Research Institute USA [8] where jet flames in the engine compartment have been investigated. Some more data was previously released by the Japan Automobile Research Institute [7]. JARI compared for a given leakage rate $(11.8 \mathrm{~g} / \mathrm{min}$ for hydrogen and $28.6 \mathrm{~g} / \mathrm{min}$ for natural gas/methane) critical diameter under which a gas flame was not sustained. They found out that the methane flame became no more viable with a rather large diameter of $2.00 \mathrm{~mm}$ or less. On the other hand, the hydrogen flame was sustained at the leak orifice even with a nozzle diameter of $1.0 \mathrm{~mm}$. Authors concluded that the favourable stability of hydrogen flames is advantageous 
as a means to avoid explosion. Needless to say that the $1 \mathrm{~mm}$ orifice considered is rather large. Much smaller leak orifice could be expected without being noticed. They could eventually cause a fire hazard. It is therefore necessary to investigate leak orifices smaller than $1 \mathrm{~mm}$. The DRIVE project will investigate these situations.

Moreover, this research institute also investigated the flame behaviour of hydrogen released from 350 bar hydrogen tanks. They found out that the hydrogen flame released upwards reached its maximum height of 7-8 meters in 5 to 10 seconds. This flame length is very significant and could cause severe hazards for cars occupants as well as for rescue services. It is therefore of a prime importance to provide advice on how this release should be dealt with (upward, downward under the vehicle...). The DRIVE project will also address this issue within this work programme.

\section{RESULTS AND DISSEMINATION}

The DRIVE project aims at investigating experimentally and numerically hydrogen vehicle related accidental scenarios in order to strengthen risk assessment as well as to promote safe hydrogen handling solution onboard vehicle. Three documents will be produced:

- the first one will address hazard quantification results and hazard quantification tools for hydrogen vehicles. Hazardous phenomena will be explained. Issues such as flame length or explosive atmosphere volume versus pressure and diameter will be detailed,

- the second one will address best practices when using CFD tools to predict hydrogen behaviour when released accidentally or under normal situation,

- and the final one will address best practices when handling hydrogen onboard vehicles. Its content will include both generic risk assessment as well as best practices for the design of hydrogen vehicles.

These results will be presented in the course of open seminars.

\section{CONCLUSIONS}

Field of investigation covers the all range of phenomena that can be encountered in hydrogen accidents from leakage, to dispersion, ignition and finally combustion. This programme aims at providing experimental and numerical results in order to provide realistic risk assessment and to be able to specify precisely expected hydrogen vehicles safety performances. DRIVE outputs will be turned into practical graphs to facilitate risk quantification. Recommendations on best practice vehicle design will also be drafted. Actually, topics such as maximum allowable explosive volume, control of ignition sources and location of hydrogen components will be addressed.
This project has just started. However preliminary reviews of existing experimental data and guidelines have been performed, to better define the expected results of the project. These reviews and early thoughts and findings represent important contributions to the elaboration of safety guidelines for hydrogen vehicles. We can without any doubt consider today that DRIVE outputs will be of a great help for designing safe hydrogen vehicles.

\section{ACKNOWLEDGMENTS}

Authors would like to thank the French National Research Agency ANR, and its hydrogen programme PAN-H, which financially supports this project.

\section{REFERENCES}

[1] Dr Fürst, S. \& al, Safety of Hydrogen-fueled motor vehicles with IC engines; Proceeding from the $1^{\text {st }}$ International Conference on Hydrogen Safey, Pisa, September 2005

[2] CaFCP Technical report, 2004, 'Support facilities for hydrogen fuelled vehicles-Conceptual design and cost analysis study', Prepared for California Fuel Cell Partnership by Parsons and Brinckerhoff in association with TIAX and University of Miami.

[3] UN GRPE Informal Group on Hydrogen/Fuel Cell Vehicles, Proposal for a new draft regulation. Uniform provisions concerning the approval of:

specific components of motor vehicles using compressed gaseous hydrogen,

vehicles with regard to the installation of specific components for the use of compressed gaseous hydrogen.

[4] Swain M.R., Schriber J.A. and Swain M.N., (1998a) "Addendum to Hydrogen Vehicle Safety Report: Residential Garage Safety Assessment. Phase-1: Risks in Indoor vehicle storage", Prepared for Directed Technologies Inc., pp 118. \& Swain M.R., Grilliot E.S.

[5] Swain M.N., (1998b) "Addendum to Hydrogen Vehicle Safety Report: Residential Garage Safety Assessment. Phase-2: Risks in Indoor vehicle storage", Prepared for Directed Technologies Inc., pp 35.

[6] Swain M.R., Grilliot E.S. and Swain M.N., (1999) "Experimental verification of a hydrogen risk assessment method", Chemical Health \& Safety, pp 28-32.

[7] T. Hayashi and S. Watanabe, (2004) "Hydrogen Safety for Fuel Cell Vehicles", Proceeding of WHEC-15, Yokohama.

[8] Presentation from Bob Zalosh at IEA Task 19 meeting on March 16-17th, 2006 
[9] ATEX 99/92/EC - Equipment and protective systems intended for use in potentially explosive atmospheres

[10] ATEX 99/92/EC - Minimum requirements for improving the safety and health protection of workers potentially at risk from explosive atmospheres

[11] Regulation No. 110 - Uniform provisions concerning the approval of:

1. Specific components of motor vehicles using compressed natural gas (CNG) in their propulsion system;

2. Vehicles with regard to the installation of specific components of an approved type for the use of compressed natural gas (CNG) in their propulsion system

[12] EN 1755 : Safety of industrial trucks - Operation in potentially explosive atmospheres - Use in flammable gas, vapour, mist and dust

[13] EN 50021 : Electrical apparatus for potentially explosive atmospheres - Type of protection " $n$ ".

[14] Guide de bonne pratique à caractère non contraignant pour la mise en œuvre de la Directive 1999/92/CE du Parlement européen et du Conseil concernant les prescriptions minimales visant à améliorer la protection en matière de sécurité et de santé des travailleurs susceptibles d'être exposés au risque d'atmosphères explosives, Commission Européenne, DG Emploi et affaires sociales, Santé, sécurité et hygiène au travail, Version finale avril 2003

[15] Health \& Safety Laboratory, Outstanding safety questions concerning the use of gas turbines for power generation - Executive report - CM/04/02

[16] C.B. Devaud \& al, Stability of underexpanded supersonic jet flames burning $\mathrm{H} 2-\mathrm{CO}$ mixtures, Shock waves (2002) 12: 241-249

\section{CONTACT}

DRIVE project coordinator: Lionel PERRETTE

Tel: +33344556339

Lionel.perretteneris.fr 